DOI https://doi.org/10.30525/978-9934-26-045-2-26

\title{
ЗАСТОСУВАННЯ КАДРОВОГО МЕХАНІЗМУ ДЛЯ СТВОРЕННЯ ІНСТИТУЦЙНО СПРОМОЖНИХ ТЕРИТОРІАЛЬНИХ ГРОМАД
}

\author{
Положешна I. B. \\ аспірантка кафедри парламентаризму та політичного менеджменту \\ Начіональної академї державного управління \\ при Президентові України, \\ головний спеціаліст відділу організаційної роботи управління \\ стратегічного планування та комунікацій \\ Міністерства молоді та спорту України \\ м. Київ, Украӥна
}

Реформа децентралізації органів виконавчої влади та місцевого самоврядування сприяє формуванню дієздатного та найбільш наближеного до громадян органу місцевого самоврядування.

Об'єднання територіальних громад дало можливість створеним органам місцевого самоврядування отримати відповідні повноваження та ресурси, що забезпечують можливості для розвитку своїх територій, створення сучасної освітньої, медичної, транспортної, житловокомунальної інфраструктури.

Станом на 10 вересня 2020 року в Україні створено 983 об'єднані територіальні громади, що становить $41 \%$ від загальної кількості громад.

Власні доходи загального фонду місцевих бюджетів в 2020 році (факт січень-липень) становлять 291,9 млрд. грн. що в 4,3 рази більше в порівнянні з 2014 роком. Також відбувається зростання доходів загального фонду місцевих бюджетів на одного мешканця. Якщо в 2016 цей показник був 2020,8 грн. то в 2020 році становить 4209,3 грн. на одного мешканця (за 5 років збільшився вдвічі).

Але на тлі позитивних зрушень, ми можемо констатувати той факт, що не всі створені громади $є$ інституційно спроможними.

Зокрема, малодослідженим та таким, що потребує подальшого вивчення залишилось питання впливу кадрового механізму на створення інституційно спроможних територіальних громад.

Питання формування і розвитку механізмів державного регулювання кадрової політики на різних рівнях соціально-економічних 
систем розглядались у роботах українських науковців В. Вакуленка, М. Мінченка, М. Щьокіна, А. Лаврова.

Разом $з$ тим виявлено: по-перше, переважна більшість науковців вивчала проблеми i механізми децентралізації на державному i регіональному рівні, а не на рівні сільських, селищних рад (базовий рівень); по-друге, в основному, науковці вважають, що спроможність громад залежить лише від фінансової децентралізації, наявності бюджетоутворюючих підприємств і великої кількості жителів громади. Але, на нашу думку, необхідно проводити комплексні дослідження 3 питань створення інституційно спроможної територіальної громади. Зокрема, мало досліджені механізми створення інституційно спроможної громади, не систематизовано проблеми діяльності громад у частині кадрового забезпечення, стратегічного планування, фінансово-економічного розвитку, співробітництва між об'єднаними територіальними громадами.

Аналізуючи проблему кадрового забезпечення в територіальних громадах, необхідно звернути увагу на те, що голови сільських, селищних рад мають виборчу посаду і періодично змінюються. Тому дуже гостро стоїть проблема фахового рівня керівників органів місцевого самоврядування. На нашу думку, необхідно внести зміни до Законів України «Про місцеві вибори», «Про місцеве самоврядування», «Про службу в органах місцевого самоврядування» в частині вимог до претендентів, які балотуються на посади голів міських, районних у містах, сільських, селищних рад а саме: «кандидат на посаду міського, селищного, сільського голови повинен мати вищу освіту за напрямком: публічне управління та адміністрування, державне управління, право, економіка, менеджмент». Також повинен враховуватись досвід на керівних посадах в органах виконавчої влади, місцевого самоврядування, інших підприємствах, установах, організаціях не менше 5 років. Якщо хоча б ці дві умови будуть витримуватись, то управлінський потенціал керівників органів місцевого самоврядування буде значно вищий.

Інше проблемне питання - це добір кадрів у структури відділів, управлінь органів місцевого самоврядування. Адже відповідно Закону України «Про службу в органах місцевого самоврядування» кадрові призначення відносяться до компетенції голів територіальних громад, які мають право самостійно, без проведення конкурсу, призначати на посади у виконавчі комітети сільських, селищних рад спеціалістів. Вищевикладене унеможливлює залучення висококласних спеціалістів до роботи в органах місцевого самоврядування, здійснення контролю за 
добором кадрів. Створюються умови для впровадження корупційних схем при зарахуванні на посади.

Тому для вирішення вищевказаних проблем та створення спроможної територіальної громади необхідно розробити HR-стратегію, яка буде стратегічним планом дій керівництва органу місцевого самоврядування для ефективного формування, освоєння і розвитку людських ресурсів із урахуванням змін стану зовнішнього середовища.

HR-стратегія повинна бути частиною стратегії розвитку територіальної громади. Цілі стратегічного управління кадровими ресурсами повинні досягати цілей, які поставленні перед територіальною громадою.

В даній стратегії повинні враховуватися чинники впливу зовнішнього і внутрішнього середовища органу місцевого самоврядування, що може викликати необхідність, внесення змін у структуру та чисельність персоналу, його рівня професійної компетентності, стилю i методів управління людськими ресурсами.

HR-стратегія сприятиме: посиленню можливостей органу місцевого самоврядування (в сфері персоналу) протистояти негативному впливу зовнішніх чинників на виконання власних та делегованих повноважень, ефективно використовувати свої сильні сторони у зовнішньому оточенні; розширенню переваг (інституційної спроможності) територіальної громади за рахунок створення умов для розвитку $\mathrm{i}$ ефективного використання трудового потенціалу, формування високопрофесійних, компетентних кадрів; повному розкриттю здібностей персоналу до творчого, інноваційного розвитку, для досягнення як цілей територіальної громади, так і особистих цілей працівників.

Крім розробки HR-стратегії органам місцевого самоврядування необхідно провести комплекс заходів, які спрямовані на пом'якшення позицій щодо відбору кадрів на ринку праці, а саме презентувати свою територіальну громаду (HR-брендинг).

На нашу думку, HR-брендинг - це діяльність щодо формування системи управління персоналом, яка дозволяє конкретній установі, організації, органу місцевого самоврядування отримати конкурентні переваги серед інших і забезпечити задоволеність персоналу організації існуючими кадровими технологіями і проєктами.

HR-брендинг переслідує декілька цілей, а саме: залучення до роботи кращих кваліфікованих кадрів; підвищення рівня продуктивності праці спеціалістів; зниження плинності кадрів.

Отже, HR-брендинг повинен стати основною складовою HR-стратегії інституційно спроможної територіальної громади.

Для якісного використання кадрового механізму в побудові інституційно спроможної територіальної громади необхідно: 114 
- розробити методику розрахунків потреби у кадрах в залежності від кількості населення територіальної громади і площі, яку вона займає та відповідні структуру і штатну чисельність органів місцевого самоврядування;

- удосконалити систему вищої та післядипломної підготовки кадрів для органів місцевого самоврядування;

- запровадити навчальні програми для посадових осіб місцевого самоврядування, депутатів місцевих рад, зокрема, 3 питань ефективного самоврядування, зміцнення матеріальної та фінансової основи місцевого самоврядування, проектного менеджменту.

Підсумовуючи викладений матеріал, доцільно зазначити, що основними механізмами створення інституційно спроможних територіальних громад $є$ кадровий, фінансово-економічний, правовий та інші. Застосування вищевказаних механізмів дадуть можливість вирішити ряд проблем, які виникають в процесі децентралізації та сформувати ряд рекомендацій, які мають на меті створення спроможних громад, а саме: внести зміни до законодавчої бази стосовно розробки критеріїв щодо зайняття посади голови територіальної громади, його заступників та інших посадових осіб органів місцевого самоврядування з метою якісного кадрового забезпечення, підготовки та перепідготовки кваліфікованих кадрів; розробити методику розрахунків потреби у кадрах в залежності від кількості населення територіальної громади i площі, яку вона займає та розробити відповідну структуру, штатну чисельність органів місцевого самоврядування; підготувати ефективні HR-стратегію та HR-брендинг.

\section{Література:}

1. Місцеве самоврядування в умовах децентралізації повноважень: навч. посіб. /А. П. Лелеченко, О. І. Васильєва, В. С. Куйбіда, А. Ф. Ткачук. Київ, 2017. 110 с.

2. Доля І. Щодо кадрового забезпечення місцевої влади в контексті впровадження адміністративної реформи: аналітична записка URL: http://www.niss.gov.ua/articles/913/ (дата звернення: 21.12.2020)

3. Павлюк А. П. Формування об'єднаних територіальних громад: стан, проблемні питання та шляхи їх вирішення. Аналітична записка. URL: http://www.niss.gov.ua/content/articles/files/terutor_gromad86ead.pdf. (дата звертання: 04.01.2021)

4. Таукешева Т.Д. Бюджетна децентралізація як чинник зміцнення місцевого самоврядування в Україні URL: http://www.kbuapa.kharkov.ua/ e-book/ tpdu/2015-1/doc/3/02.pdf. (дата звернення 09.01.2021) 